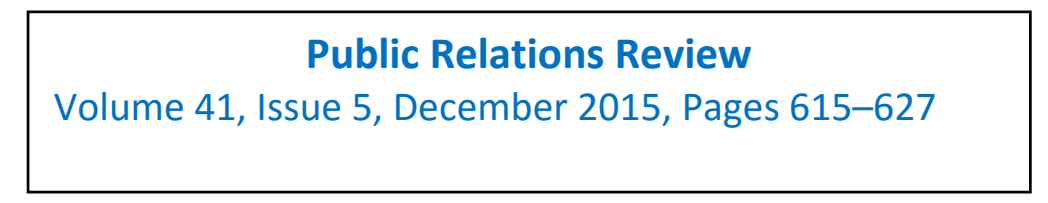

\title{
Scott Davidson
}

Department of Media and Communication, University of Leicester, Bankfield House, Leicester LE1 7JA, United Kingdom

\section{EVERYWHERE AND NOWHERE: THEORISING AND RESEARCHING PUBLIC AFFAIRS AND LOBBYING WITHIN PUBLIC RELATIONS SCHOLARSHIP}

\begin{abstract}
Public affairs and lobbying is a high status and strategically vital public relations specialism. It is a field of PR practice that generates high levels of both scholarly and public concern in regard to its perceived role in supporting corporate power and the associated impact on the functional legitimacy of democratic institutions. For this paper a content analysis was conducted of academic journals (between 2000-2013) to provide insights into how public affairs and lobbying have been theorised and researched within public relations scholarship and to ascertain to what degree wider public concerns have been addressed. Findings include an empirical confirmation of the low level of research activity on public affairs; that stakeholder and rhetorical theories have been the most widely used theories, but are far from constituting dominant paradigms; that scholarship has privileged functional objectives over civic concerns; and that published work originates almost entirely from institutions in Europe and the US with the Global South invisible. The paper also discusses future directions for research in public affairs and advocates the placing of discourse into definitions of public affairs, and that academic public relations should assert responsibility for this field, but in a manner that more equitably balances organisational and societal concerns.
\end{abstract}

Keywords: Public Affairs, Lobbying, Public Relations Theory, Discourse, Relationships, Campaigns

\section{Accepted version}

Citation: Davidson, S. (2015). Everywhere and nowhere: Theorising and researching public affairs and lobbying within public relations scholarship. Public Relations Review. Volume 41, Issue 5, December 2015, Pages 615-627 


\section{Background}

The centrality of the public affairs function within public relations in combination with the ongoing concerns regarding impacts on democratic decision-making, as well as popular assumptions of routinely low ethical standards present a strong normative case for this field to be a priority for theorising and research. While definitions of public affairs may still be in a state of flux, scholars who have explored this function have tended to agree on its significance as a specialism. Zetter mischievously nominated public affairs as constituting "PR for grown-ups" because of the "huge rewards for getting it right - and major consequences for getting it wrong" (2008: p. :xiii). Public affairs has been observed as higher status strategic work (L'Etang, 2008), and that specialists are more than "mere technicians" but professionals who wield influence in shaping internal and external realities for an organisation (de Lange and Linders, 2006: p. 133). In Europe lobbying has been identified as one of two recognised management functions for communications professionals (Beurer-Zuellig et.al., 2009), and Harris and Moss (2001) have argued that public affairs practitioners need to engage in forms of dialogue at governmental and societal levels that generally require more complex solutions than those required in carrying out market-related promotional campaigns.

Alongside the strategic significance of public affairs as a function has been the ongoing global growth in demand for its services. There has been recent and rapid growth in interest group participation in policy making in Australia (Ward, 2009) and in Italy a new emphasis on creating stakeholder dialogue in public administration has resulted in large increases in public affairs related revenue for the public relations industry (Valentini, 2009). Additionally Macnamara (2012) found that government relations and public affairs were the third most prominent fields of practice discussed in text books adopted on university courses on public relations.

In a similar fashion to public relations more widely, there have been ongoing debates that have yet to reach an established consensus on a definition of public affairs. In 1998 Baumgartner and Leech concluded that there was no consensus among scholars on what they meant by lobbying and more recently McGrath et al. (2010) observed that public affairs is often used as a euphemism for lobbying or simply can be the preferred term in which an organisation titles its public relations operations, while Verčič and Verčič (2012) concluded there is no agreement on how lobbying fits into public 
relations practice and Wise (2007) suggested this is part of a wider problem of researchers ignoring specialised fields of practice. Toth (2006) defined public affairs as a public relations specialisation that is focused on building public policy relationships between organisations. A significant proportion of scholarship has been primarily interested in researching corporate contexts, which helps explain why Windsor (2005) defined public affairs as the interface between corporations and their non-market environments. This is partially echoed by McGrath et al's. (2010) positioning of public affairs as being in the nexus of politics, management and communication. Milbraith (1963) provided a widely adopted definition of lobbying that emphasised it was a communicative act aimed at influencing governmental decision-makers, but while lobbying may lend itself to simpler definitions public affairs is a more diffuse function that as Harris and Moss (2001) argued is centred on managing relationships that may have policy implications with a broader range of stakeholders.

Part of the difficulty in defining and conceptualising public affairs as a specialism of public relations is that a considerable proportion of public affairs practice is indistinguishable from public relations activity (Somerville and Ramsey, 2012). By way of example, in written evidence to a committee of the UK parliament that was investigating the regulation of lobbying, Ed Williams then CEO of Edelman UK argued that for large agencies such as his “...public affairs is just one of many public relations services we provide to clients. The boundaries between, for example, activity which influences the political environment and activity which influences a broader media and stakeholder environment is increasingly blurred." (Political and Constitutional Reform Committee, 2012: p. 67).

In most definitions public affairs is a function that seeks to influence policy environments and political decision making by those who are not elected politicians or civil servants. However, a further complication is that in US contexts public affairs is often the term used in reference to public relations practitioners working for government departments. This originates from the 1913 Gillett Amendment that stated publicity activities must only come from funds specifically defined for such work. Furthermore, after the first waves of scholarship on political communication management which were developed within political marketing frameworks there is 
now a growing interest in the emerging field of political public relations. An important text book in developing this field defines the discipline as a management process involving purposeful communication for "political purposes" Stromback and Kioussis' (2011: p. 8). This definition places public affairs as a function that can be researched within a shared framework with studies exploring governmental communications and election campaigning. As with public affairs practice governmental public relations initiatives impact on the public's ability to receive adequate information in order to evaluate public policy choices (Rice and Somerville, 2013). Government public relations, and the activities of parties and candidates who wish to assume executive power at some future point, are critical determinants of the external environments within which public affairs practitioners operate. However, for what is already a diffuse field of study, it can be unhelpful to blur the boundaries further when there is an available operational consensus, for this paper and other studies, that public affairs practitioners are not, or seeking to be, elected politicians.

There is also an impetus for public relations scholars to theorise and research public affairs based on its political significance and its perpetual desire to influence policymaking at all levels from the hyper-local to global treaty negotiations. These normative expectations are multiplied when the widespread civic and scholarly concerns regarding the nature and impacts of lobbying on real-world policy-making are recognised and acknowledged.

Scholars who draw upon political economy frameworks to study public relations and lobbying emphasise how communications and relationships are built within wider structures and processes of power, and explore inequalities of resources available to different groups. Miller and Harkins (2010) argue public relations and lobbying are deployed by corporations who pursue their interests by dominating decision-making environments. Not only does lobbying enable the communicative agency for asserting corporate power, ethical standards are low and routinely involve deception and manipulation (Stauber and Rampton, 1995, Dinan and Miller, 2007). Corporations use communications and lobbying to undermine global efforts to implement environmental policies on sustainable development (Beder, 2002) and similar campaigns to frustrate public health initiatives to restrict the tobacco industry have also been well documented (Saloojee and Dagli, 2000). These critiques chime with wider public and media 
discourses that portray public affairs as involving "influence peddling" and "corridor creeping" (Moloney, 2006: p. 91) that are then further amplified by scandals relating to the activities of figures such as "Casino" Jack Abramoff (Stone, 2006) and the corruption inquiries and trials related to his activities in the US. Indeed a recent report by the OECD expressed concern that "a sharp and damaging ethical schism has emerged in many countries between the lobbying profession and the public" (OECD, 2009: p. 17).

In the context of public affairs' significance as a high status public relations specialism that generates considerable levels of public concern in regard to its perceived impacts on democratic decision-making, this paper seeks to establish how public affairs has been theorised within public relations scholarship. A particular concern was to ascertain what kind of balance has existed between research that is oriented toward functional concerns that privilege organisational interests and studies that privilege the needs and concerns of civic society. The paper reviews the limited number of previous attempts to establish theoretical frameworks for exploring public affairs as a public relations specialism. It then evaluates the balance between functional and civic orientations in previous overviews of public affairs as a field of study placed in the context of the growing interest in addressing the broader functions of public relations practice within democratic systems. The paper reviews previous content or bibliometric analyses of papers published in academic public relations journals before presenting the results of this study's analysis of public affairs articles in PR academic journals in the period between 2000 and 2013. Finally, drawing upon the findings of the content analysis, the paper discusses the body of knowledge in public affairs research and its orientations, including the proposal for a new definition of public affairs.

As will be seen in the next section, scholars have generally been disappointed with the volume and quality of public affairs research. These weaknesses suggest resonances with the wider problems in public relations scholarship identified by McKie (2001) where scholars predominantly address problems from organisational perspectives weakened by what Cheney and Christensen, (2001: p. 179) argued has been the illusion of symmetrical dialogue, implicit corporatism, and Western managerial rationalism. The next section begins by considering previous overviews of public affairs within public relations publishing. 


\subsection{Theorising the public affairs specialism}

Although Meznar (2001) observed that there was a large but disorganised public affairs literature, only a small proportion of this research can be found in publications located within the parent discipline of public relations, and lobbying in particular only receives minimal attention (Johnson, 2005). So much so that Tusinski Berg (2009) was led to conclude that in regard to lobbying, public relations research constituted little more than cursory descriptions. The paucity of the literature is evidenced through Wise's (2007) paper on lobbying and relationship management, which in its literature review, in a sub-section on "lobbying in the public relations literature", was limited to a short discussion of a single publication - Terry's (2001) interpretive study of the selfperceptions of practitioners based in Texas.

In the early stages of public relations' development as a distinct academic discipline there were efforts to apply the then dominant symmetry-excellence paradigm. A significant example is Toth's (1986) attempt to conceptualise directions for public affairs research within public relations scholarship through applying what she argued were the two "signature" contributions by James Grunig, namely his situational theory of publics and his positing of the relationship between environmental constraints and symmetrical or asymmetrical modes of communication. Grunig and Jaatinen (1999) sought to apply symmetrist paradigms to government communications. This paper is notable for how Grunig and Jaatinen argue that issue networks that form when government communicators practice symmetry can be seen as representing a form of collectivist collaboration to which advocates of pure pluralism would object. However, despite the dominant position of the symmetry-excellence paradigm during this period, there has been little interest in advancing a collectivist interpretation, or otherwise, of Grunig's work to public affairs.

Toth (2006) provided another significant contribution in a chapter on public affairs within Botan and Hazleton's textbook on public relations theory. Here Toth argued that although public affairs theorising was still minimal there were several established public relations theories that could be used as staring points for discussing public affairs. Excellence and situational theory were still prominent in the suggested starting points, but Toth also nominated communitarianism and social capital as paradigms for building new research agendas that would allow consideration of wider questions 
regarding the place of values and the importance of community building. Published four years later Heath's Sage Handbook of Public Relations (2010) has drawn endorsements from scholars for its breadth and diversity in providing an overview of public relations scholarship (Ihlen and Verhoeven, 2012). In the handbook's subject index there is only one entry for public affairs and no mentions of lobbying, although concepts that sit within public affairs' conceptual aegis, such as activism, advocacy, community relations, issues management, power and governance are present throughout the index. Here, as in other areas of public relations publishing, public affairs is everywhere and nowhere at the same time.

In the last decade and a half there have been significant developments in specialist publishing on public affairs such as the launch of the Journal of Public Affairs in 2000 and the publication of Harris and Fleisher's Handbook of Public Affairs in 2005. The public affairs specialist literature as evidenced by the contents of the handbook tends towards making the same functionalist assumptions identified by Edwards (2012) in the public relations field as a whole. These assumptions are built around privileging organisational contexts and the conceptualisation of community and civic life through the lens of the organisation's strategic interests.

In publications that have sought to provide overviews of public affairs scholarship, there have been a number of authors who have either implicitly made assumptions that privilege organisational perspectives, as well as other more explicit calls to privilege corporate needs, but with at least a degree of recognition of the need to address the interests of civic society. Fleisher and Blair (1999) in exploring public affairs in relation to public relations criticised the latter for not fully incorporating the language of business management. Getz (2001) advocated a thematic focus on why do firms (author emphasis) become politically engaged. In a similar vein Hillman (2002) argued the research areas within public affairs should be integrated through agreeing to use "firm performance" as a common dependent variable, in this case leaving social impacts as a concern for other academic fields. For Boddewyn (2012) public affairs research should orientate to understanding how some firms outperform others in nonmarket environments and that "nonmarket" should appear in definitions of public affairs. Fleisher (2012) continues to argue public affairs should be working to align organisational values with the public's interests, in a similar vein Boddewyn (2012) 
suggested practitioners should be activists who pro-actively identify social concerns and find ways of contributing to their solution. While McGrath el al. (2010) predominantly conceptualise public affairs as a corporate activity, they argue the value of the function is best realised when it acts as an ethical balance against the profitmotive as the sole driver of corporate decision making.

As established earlier in this section there have only been a limited number of articles that have attempted to provide theoretical overviews of how public affairs fits into wider public relations frameworks and paradigms. There has been a growing interest, however, in addressing the overall function of public relations practice within democratic systems and the associated issues of power and hegemony.

The rhetorical paradigm (Heath et al., 2009) for researching public relations has been one of the most significant non-managerial paradigms for developing the field, and has tended to be the framework through which critical scholars have posited the value of locating public relations practice as the professionalisation of deploying language in order to negotiate or maintain positions of power. Indeed Heath et al. (2013) remain optimistic that even in the context of apparent corporate domination of policy arenas that public relations can still assist society in achieving more democratic outcomes. However, they admit this would require multiple voices with the ability to draw upon rhetorical resources engaging with each other within a shared commitment to collective decision-making.

Smudde and Courtright (2010) also identified rhetorical power as one of the most important dimensions of public relations influence on society, a power that requires the ability to effectively manipulate language and symbols. Motion and Leitch $(1996,2009)$ outlined the potential for public relations to be researched through the framework of discursive strategies to gain public consent in order to pursue organisational objectives. In this paradigm public relations is a process of creating meaning through discourse that establishes or reinforces particular truths and that practitioners can be conceptualised as "discourse technologists" who seek to maintain or transform discourses. Within this framework critical discourse analysis becomes a valuable methodology for exploring the political implications of public relations practice and how it might influence social change in democratic societies (Motion and Weaver, 2005) 
or for exploring public affairs battles to establish Foucauldian regimes of truth through framing and storytelling (Somerville, 2011). Ihlen and Verhoeven (2012) argue that if academic public relations is to be taken seriously, then issues of power, behaviour and language need to be dealt with, while practitioners actively engaged in academic research such as McGrath (2007) have also argued that use of language specifically by lobbyists is an important potential direction of research for both academics and practitioners.

Scholars have also drawn on the work of French sociologist Bourdieu to suggest public relations power can be explored through its position as a socially embedded profession that engages in struggles for internal professional legitimacy, as well as for external legitimacy for the organisation (Edwards, 2006, Ihlen, 2007). In the context of public affairs Bourdieuian notions invite us to consider that as cultural intermediaries practitioners promote a particular type of habitus of what is more attractive and logical in terms of what constitutes a good citizen (Edwards, 2012). Indeed, De Lange and Linders (2006) suggest that in studies on public affairs scant attention has been given to more implicit and symbolic forms of power. By way of example they describe how consultancies develop prestigious office spaces in geographical centres of power, invite senior political and media personalities to their parties and many public affairs managers: "...mentioned their social networks as their most important tool in their work. Some gave us examples of how they brought people of high esteem (for instance scholars of international fame) into the arena in order to make use of the symbolic power of their reputation" (De Lange and Linders, 2006: p. 138).

The work of Habermas $(1989,1996,2006)$ and his theories of the public sphere and strategic communicative action have also been applied when evaluating the impact of public relations on democracy and the quality of policy-making. Habermas conceived of two basic spheres. The first is an informal sphere where voluntary associations and interest groups participate in discourse and reach understandings on issues of concern. The other more formal political sphere of institutional arenas such as parliaments and political parties are specifically designed to take decisions. Normatively the decision making sphere should be porous and open to considerable influence from the informal civic sphere (Finlayson, 2005). The systems world of technocratic goals is problematised as having been captured by the logic and special interests of money and power and has 
been decoupled from the lifeworld of family and culture. In these contexts public relations can be associated with the use of language to pursue the strategic needs of the system rather than being a means of reaching mutual understanding, its role can be seen as positive if motivated by a desire to attain mutual understanding, but unethical if entries into public discourses are purely strategic - indeed individuals can be potentially liberated through communicative action, but alienated through strategic action (Holmström, 1997). Further utility can be found in Habermas's theory of communicative action through offering visions of ideal speech situations and providing a vocabulary for examining claims and assertions that are put forward in the public sphere (Meisenbach and Feldner, 2007), and his theories can be drawn upon to build conceptualisations of how public relations can develop processes of understanding (Burkart, 2009) as evidenced by Meisenbach's (2006) application of discourse ethics to practical scenarios.

The public sphere's positing of discursive spaces for researching synergises with other streams of public relations scholarship that have focused on the ideas of civil society and social capital. For Taylor civil society should be conceptualised as a network of associations and discursive communities that exist outside of the state. Significantly this framework is built by drawing upon Hauser's (1998) more optimistic assumptions than those of Habermas in regard to the possibility of civic spaces becoming co-opted or captured by elite interests. This framework also draws upon Putnam (1995) to argue that public relations contributes to democracy by the social capital that is generated when the advocacy work of organisations and voluntary associations generates trust and cooperation between citizens and increases levels of engagement and participation (Taylor 2009, Yang and Taylor, 2013). Within this vision the objective of building civil society arrives through the promotion of engagement and vibrant discursive spaces. However, the uncritical acceptance of functionalist assumptions that organisations should second-guess and prevent the development of active groups of citizens (Demetrious, 2013), has contributed to the delayed development of critical explorations of civil society paradigms of public relations.

\subsection{Content and bibliometric analyses of public relations scholarship}


To date there have been no published studies on how public affairs has been theorised within public relations scholarship. However, there has been a stream of work that has attempted to review academic public relations research as a whole, and one of the objectives of this paper is to make a contribution to this stream.

Ferguson (1984) was one of the earliest attempts and her study is still widely cited and has been used on several occasions to inform the design of other bibliometric or content analyses of public relations scholarship. Ferguson analysed the abstracts of articles that had been published in Public Relations Review. The study was influential for its advocacy and prediction that relationships offered the best opportunities for theory development. Sallot et al. (2003) sought to extend the Ferguson study by modifying her categories and analysing the content of whole articles. In their results, $19.8 \%$ of the articles sampled were coded as "theory development", a substantial increase on the $4 \%$ found in Ferguson. The largest sub-category coded theory development were papers concerned with symmetry or Excellence Theory, but this category only accounted for $13 \%$ of the theory development articles, and the authors concluded that no dominant-paradigms had emerged in their study. Zoch et al. (2007) adapted their categories and variables based upon the approaches used by Ferguson and Sallot et al. and extended the analysis to a wider range of academic journals. They coded $22 \%$ of articles in the sample as theoretical. More recently Sisco et al. (2011) have also attempted to extend Ferguson's framework. After some modifications to the original classifications they found that $22 \%$ of articles from seven journals were coded as "theory-oriented". Significantly, they discussed their deployment of rather generous definitions of "theory-oriented" and far fewer articles would have been included in this category if a stricter definition had been used. In conclusion Sisco et al. observed that relatively few articles in their sample focused on building or proposing theoretical approaches and that there was an imbalance between professional and theory-oriented articles - a "disheartening" finding for those believe this is an indicator of the field's maturity. In addition to studies which have developed Ferguson's framework, other research publications that have used other approaches have also expressed disappointment at the quantity and quality of theory in PR publications. Cutler's (2004) analysis of articles published in Public Relations Review found over two thirds of the sample did not attempt to test or develop theory. An early study by Pavlik (1987) had concluded that critical research was 
virtually non-existent. Zoch et al. (2007: p. 19) stated that they were less optimistic than Sallott et al. (2003) about the progress being made in building theory, arguing the field may have plateaued and "Overall, research is still focusing on specific topics

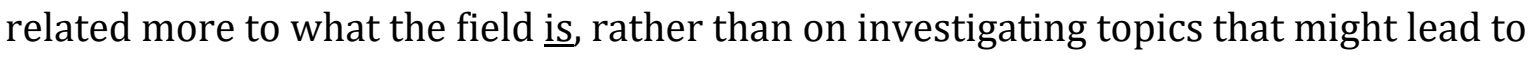
advancing the field through building and developing theory". Macnamara (2012) analysed the twenty textbooks that have been most widely adopted in public relations courses in Australia, and found that across 19 of these books there was only 28 pages concerned with theory. Some common textbooks were essentially atheoretical.

Citation analysis has been used as a methodology to evaluate public relations scholarship by Yorgo Pasadeos and colleagues in three studies conducted nearly twenty years apart (Pasadeos and Renfro 1992, Pasadeos et al., 1999, Zoch et al., 2007 and Pasadeos et al., 2010), and was also used by Morton and Lin in 1995. Pasadeos and Renfro (1992) argued the value of citation analysis is that it allows an assessment of the impacts of authors, institutions and schools of thought. In 1999 Pasadeos et al. found that their largest subject category of cited works was "public relations roles", followed by "management and corporate public relations studies" and "models". In an update of this citation analysis (Pasadeos et al., 2010) many of the general trends from the previous studies were confirmed, but this time they found a "generational shift" due to the replacement of Grunig and Broom by Taylor, Cameron and Hallahan as the most cited authors. The value of Morton and Lin's (1995) study was limited by their decision to only look at articles published in Public Relations Review but in doing so provided an illustrative picture of public relations scholarship in this period as all authors in the sample were based in North American institutions. Their study indicated the regional and cultural skew of published scholarship in this early period in academic public relations.

Indeed Morton and Lin (1995) are also indicative of the dominance of functionalist managerialism during this period as evidenced by their decision to create "technical", "management", "professionalism" and "others" as their four topic categories. Reviews of the field at this time revealed a dominant paradigm in public relations research that privileged functional issues and which was firmly oriented towards seeing the world through the eyes of management. Over a decade later, Jelen's (2008) content analysis of 
journal content equally led her to speculate that public relations as a discipline in the early $21^{\text {st }}$ Century was still evolving mainly around managerial concepts.

Finally, for this study, it is important to acknowledge two recent studies that have looked at how specific elements of public relations theory and practice have been researched. An and Cheng's (2010) study undertook a thematic meta-analysis of theories and topics in crisis communication research, while Ye and Ki (2012) focused on the rigour of public relations research concerned with the internet.

\section{Methodology}

To generate new data on how public affairs and lobbying have been theorised and researched within public relations scholarship a content analysis of published journal articles was conducted. A secondary objective of the content analysis was to evaluate the balance between research that has privileged functional perspectives and work that has privileged the concerns of civic society.

The study searched for papers to analyse from all articles published between 2000 and 2013 in Public Relations Review, the Journal of Communication Management, Public Relations Inquiry, PRism, Public Relations Quarterly, Public Relations Journal, the Journal of Public Relations Research, and the Journal of Public Affairs. No other previous studies of the field have included the Journal of Public Affairs as well as the frequently omitted PRism and the Journal of Communication Management.

Each journal was searched electronically for the key words of "public affairs" or "lobbying". The full text of the articles were examined and were included if public affairs or lobbying constituted the dominant theme or framework of the article.

Articles were coded by the author for the theories that were applied and if theory was prominent. For an article to be coded as theory prominent then a theory needed to be named, discussed and used to inform the research design or in the analysis of the results. If an article only included brief or passing mentions of a theory this was not considered as sufficient for coding as theory prominent. 
The epistemological orientation of papers was also coded using definitions adapted from de Bakker et al's. (2005) bibliometric analysis of CSR research. As with public relations scholarship the CSR literature is known initially to have been predominantly normative in nature, but over time there is an expectation that academic fields will begin to develop more prescriptive or theoretical concepts (de Bakker et al. 2005). The adapted categories for epistemological orientation were coded to the following definitions:

Conceptual - This code was applied if the paper's focus was on developing propositions or relations between theoretical constructs. No new empirical data has been collected for papers in this category.

Exploratory or Predictive - This code was applied if the paper's focus was on developing or testing (refutation, confirmation) propositions, hypotheses and relations between theoretical constructs, based on analysis of new empirical data.

Instrumental prescriptive or normative - This code was applied if the paper's focus was on providing prescription for practitioners that are either, instrumental in the realisation of some desired end or improved performance, or normative in terms of establishing some ethical or moral expectation of professional practice.

Descriptive - This code was applied if the paper's focus was to report on facts, events, behaviour or opinion with no intention or attempt to make a theoretical or prescriptive contribution.

To evaluate to what degree the civic and critical concerns regarding the impact of public affairs and lobbying on democracy had been addressed articles were also coded on the basis of the orientation of the writing. Codes were applied that categorised articles as either wholly or mainly privileging functional or civic perspectives.

Finally a range of other attributes such as authorship and institutional affiliations were recorded to enable a demographic dimension to be added to the analysis. 


\section{Analysis}

In total 104 articles met the criteria for inclusion in the sample. The sample (Table 1.) was dominated by the Journal of Public Affairs which accounted for over two-thirds (69.2\%) of the articles which were analysed. Public Relations Review and the Journal of Communication Management were the only other journals to contribute a significant number of articles at $11.5 \%$ each. The other journals that were searched for this paper only produced a handful of items that met the sampling criteria. During the 13 year sampling period the journals PRism, Journal of Public Relations Research, Public Relations Quarterly or the Public Relations Journal were not regular publishers of work that explores the PR functions of public affairs and lobbying. If this study had replicated An and Cheng's (2010) decision to only sample from Public Relations Review and the Journal of Public Relations Research then so few articles would have met the criteria for inclusion then an analysis would have not been feasible.

Table 1. Number of published articles analysed by journal name

\begin{tabular}{|l|l|l|}
\hline Journal Title & Frequency & Percent \\
\hline Journal of Public Affairs & 72 & 69.2 \\
\hline Public Relations Review & 12 & 11.5 \\
\hline Journal of Communication Management & 12 & 11.5 \\
\hline Journal of Public Relations Research & 4 & 3.8 \\
\hline PRism & 2 & 1.9 \\
\hline Public Relations Quarterly & 1 & 1 \\
\hline Public Relations Journal & 1 & 1 \\
\hline Total & 104 & 100 \\
\hline
\end{tabular}

The volume of articles published over the time period of this study (Table 2.) did not suggest any kind of significant increases in research activity on public affairs and lobbying within PR scholarship. There is a spike of publishing from 2001 to 2003 which is partially explained by the launch of the Journal of Public Affairs in 2001 and the associated editorial stimulus that encouraged submissions that took an overview of the field.

Table 2. Date of publication 


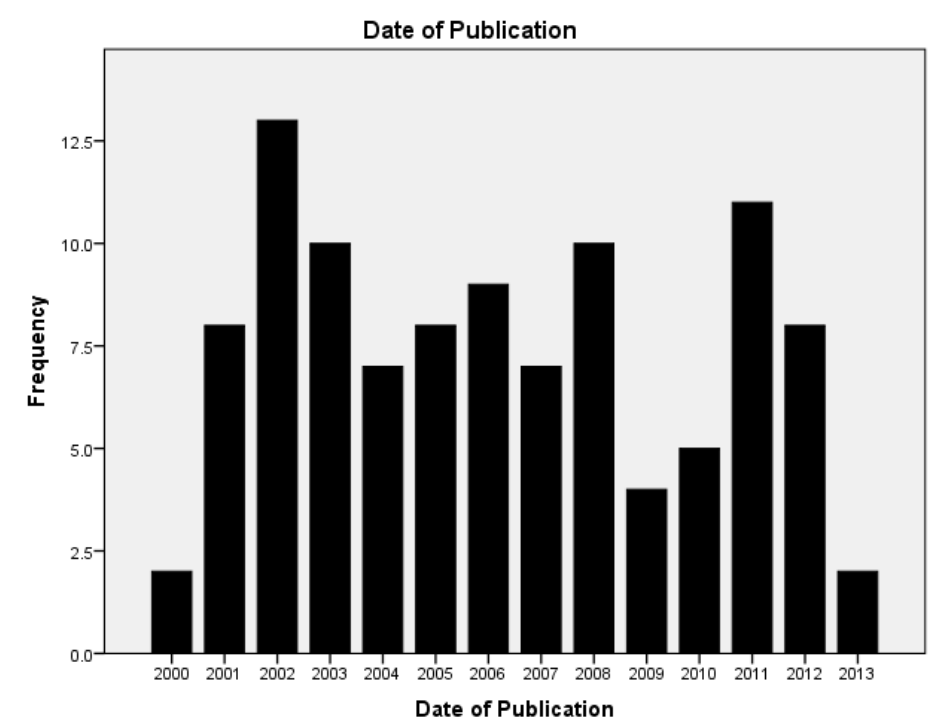

Out of the 104 articles included in the analysis, there were 91 different combinations of single or joint authorship (Table 3.). Conor McGrath who is notable for his status as being active in both Ireland and the UK as a public affairs practitioner as well as holding academic positions was the most active writer during this period. It is worth noting that although a large number of papers with authors with institutional affiliations in the USA are in the sample as a whole, none of the five authors with the highest number of publication credits are American, instead they are European or Canadian. Despite the historical significance of US scholars, within this sample there were no American public relations academics making regular and significant contributions to research on public affairs.

Table 3. Most frequently published authors within the sample

\begin{tabular}{|l|l|l|l|}
\hline Name of Author & $\begin{array}{l}\text { Single-authored } \\
\text { items Only }\end{array}$ & Name of Author & $\begin{array}{l}\text { Single and joint- } \\
\text { authored items in } \\
\text { total }\end{array}$ \\
\hline Conor McGrath & 7 & Conor McGrath & 9 \\
\hline Craig Fleisher & 5 & Craig Fleisher & 5 \\
\hline Rinus Van Schendelen & 3 & Phil Harris & 4 \\
\hline$\varnothing$ yvind Ihlen & 3 & Rinus Van Schendelen & 3 \\
\hline Valerie Terry & 2 & $\varnothing$ yvind Ihlen & 3 \\
\hline
\end{tabular}

When the institutional affiliations of authors are grouped by continent (Table 4.) the total domination of Europe and North America can be seen. Indeed if authors based in Oceania are added to those of Europe and North America then together they account for over $97 \%$ of the sample. The only papers to not include an author based in those 
continents were one from South Africa and one from Israel. Research from authors based in Africa, Latin America or from the whole of Asia represented only a tiny proportion of the work published during this sampling period. Research on public affairs within PR scholarship is largely based in two regions and by no means could it be said to be fully global in composition. Perspectives and voices from the Global South were not present.

Table 4. Institutional affiliation of authors within sample by continent

\begin{tabular}{|l|l|l|}
\hline Author/s Institutional Affiliation & Frequency & Percent \\
\hline North America & 48 & 46.2 \\
\hline Europe & 47 & 45.2 \\
\hline Oceania & 6 & 5.8 \\
\hline Africa & 1 & 1 \\
\hline Asia & 1 & 1 \\
\hline Europe/Latin America & 1 & 1 \\
\hline Total & 104 & 100 \\
\hline
\end{tabular}

The proportion of articles in the sample that were coded as having theory prominent in their writing was just under 34\%. This compares well with Sallot et al. (2003) who found just under $20 \%$ of articles were theoretical and $22 \%$ found by both Zoch et al. (2007) and Sisco et al. (2011). The proportion of articles with theory prominent also compared well to related academic fields, for example, with Potter and Riddle's (2007) content analysis of journal articles concerned with mass media effects that found $35 \%$ of articles featured a theory prominently.

In terms of epistemological orientation (Table 5.), papers that used theory to either develop conceptual frameworks or to assist research designs that sought to generate data and findings in order to explore or predict phenomena accounted for over a quarter of the sample (28.8\%). The natural concern within public affairs research on impacts and forms of practice was reflected in the $30.8 \%$ of the sample that was coded as instrumentally prescriptive or normative - holding objectives related towards exploring and proposing standards of practice. However, as with public relations research more generally, by far the greatest proportion of papers were descriptive in orientation. Descriptive research clearly has its place and there were some important and high quality contributions within the sample in this category, however, it can be 
argued that the presence of more than $40 \%$ of articles being descriptive in orientation does not represent the correct balance for a field that needs to be developing, consolidating and extending its theoretical base.

Table 5. The Epistemological Orientation of papers within the sample

\begin{tabular}{|l|l|l|}
\hline Epistemological Orientation & Frequency & Percent \\
\hline Conceptual & 12 & 11.5 \\
\hline Exploratory or Predictive & 18 & 17.3 \\
\hline $\begin{array}{l}\text { Instrumental prescriptive or } \\
\text { normative }\end{array}$ & 32 & 30.8 \\
\hline Descriptive & 42 & 40.4 \\
\hline Total & 104 & 100 \\
\hline
\end{tabular}

A total of 40 articles included identifiable and named theories in their writing (Table 6.). This number is higher than the 35 articles that were coded as theory prominent. This was because in a small number of articles theory was discussed or incorporated for a minority proportion of the writing, not sufficiently so to justify coding as prominent but constituting more than mere passing mentions. As an aim of this paper was to identify and analyse the use of theory in public affairs research in these instances the named theories were recorded under this category.

The most frequent category was the six articles that discussed and used a number of theories, these were typically conceptual papers that were based upon literature reviews. For articles that named and used a single theory, stakeholder theory occurred with the highest frequency, but with only five occurrences it is not possible to argue that this or any other single theoretical approach dominated the scholarship within this sample. Rhetorical theories may have been coded as the highest frequency if the language-oriented agenda setting articles had been merged into a single category. Excellence and systems theories had been described as dominant in other PR bibliometric studies (Pasadeos et al., 2010). Elements of this paradigm were to be found in the two articles coded as using systems theories, the two articles that used game theory and the one that drew upon Grunig's situational theory of publics. In this sample systems/excellence theories were a small but discernible presence, but not a dominant paradigm. 
Table 6. Frequency of main theories named by authors within the sample

\begin{tabular}{|l|l|}
\hline Theory used & Frequency \\
\hline Multiple Theories Reviewed & 6 \\
\hline Stakeholder & 5 \\
\hline Rhetorical & 3 \\
\hline Agenda Setting & 3 \\
\hline Relationship Management & 3 \\
\hline Systems & 2 \\
\hline Interest Group Pluralism & 2 \\
\hline Game Theory & 2 \\
\hline Social Capital & 1 \\
\hline Ethical & 1 \\
\hline Bakhtin Carnivalesque & 1 \\
\hline Corporate Political Activity & 1 \\
\hline Constructionism & 1 \\
\hline Foraging & 1 \\
\hline Resource-based view of the firm & 1 \\
\hline Political Marketing & 1 \\
\hline Private Interest Theory & 1 \\
\hline Dependency & 1 \\
\hline Situational & 1 \\
\hline Broom and Smith Practitioner Role & 1 \\
Models & \\
\hline Wyn Grant Insider and Outsider Groups & 1 \\
\hline Public Diplomacy & 1 \\
\hline Total & 40 \\
\hline
\end{tabular}

A large majority (77.9\%) of the articles sampled privileged functional concerns or perspectives in one form or another. In terms of incorporating a concern for democracy or wider civic society, over half of the articles in this study were coded as allocating no concern or allocating only brief mentions. $37.5 \%$ of the total sample privileged functional perspectives but did so by including civic concerns or perspectives as a subtheme. A minority (22.1\%) of articles in the sample privileged civic or democratic concerns. By proportion this could be considered as indicating a significant stream of research that is addressing critical concerns regarding public affairs practice, however, and putting this into a wider perspective, this represents just 23 articles at an average of fewer than two per year over a period of 13 years across eight public relations journals. 
The article topics were recorded and then merged into larger themes (Table 7.). The most frequently occurring topic themes were concerned with strategies and tactics $(20.2 \%)$ followed by industry trends/external political changes $(16.3 \%)$. There was a steady stream of articles that focused on the regulation of lobbying (12.5\%) and 8.7\% of articles explored various dimensions of corporate affairs, although there were no similar strands that focused on organisational dimensions related to NGOs or activist groups. A majority of articles were focused on how public affairs and lobbying is practiced and managed, how its environments and arenas are constituted or changing, and on how it is regulated.

Table 7. Frequency of article topics within the sample

\begin{tabular}{|l|l|l|}
\hline Article Topic & Frequency & Percent \\
\hline PA \& Lobbying Strategies and Tactics & 21 & 20.2 \\
\hline PA Industry Trends and/or external political changes & 17 & 16.3 \\
\hline Lobbying Regulation & 13 & 12.5 \\
\hline Policy Arenas & 13 & 12.5 \\
\hline PA \& PR Scholarship or Applied Evaluation Methods & 9 & 8.7 \\
\hline Corporate Affairs & 9 & 8.7 \\
\hline Practitioner Roles, Functions and Skills & 8 & 7.7 \\
\hline Lobbying in transitional democracies & 5 & 4.8 \\
\hline Media Relationships & 2 & 1.9 \\
\hline Internationalisation & 2 & 1.9 \\
\hline All Other & 5 & 4.8 \\
\hline Total & 104 & 100 \\
\hline
\end{tabular}

\section{Discussion}

Despite the centrality of public affairs to both public relations scholarship and practice, the field has largely ignored public affairs and failed to address specific civic concerns in relation to lobbying. This research also suggests that the field privileges functional concerns and the needs of upper-management in a manner that resonates with other strands of scholarship within the subject, such as Coombs and Holladay's (2012) observation that research on public relations history is itself guilty of erroneously defining public relations as solely a corporate pursuit, or Dutta's (2011) concern that public relations is too often concerned with reducing the ability of activists to challenge business activities. The results of this study also suggest a concurrence with Valentini et 
al's. (2012) assertion that the field rarely examines theories of society, uncritically assumes the superiority of familiar forms of democracy and capitalism and fails to recognise that the ability to build relationships is a form of power. When conceptualising practitioner interactions with civic society authors are sometimes more comfortable in positing the importance of issues management - ostensibly and logically a sub-function of public affairs - as social and political issues can then be researched through instrumental imperatives such as the strategic planning practice of categorising issues as either threats or opportunities for the organisation. Likewise modernistic managerialism facilitated the acceptance of Excellence Theory's orientation toward discussing public opinion and civic activism as either supporting or constraining the ability of the organisation to pursue upper management goals (Grunig et al., 2002). A civic orientation strand in public affairs research exists, but has yet to realise its potential for altering the self-perceptions of both practitioners and scholars in a direction where they widely adopt an identity as pro-active advocates of civic participation as well as increased environmental responsibility and social justice. This civic orientation holds great promise and is likely to become an increasing focus of public relations scholarship and qualitatively different but significant works such as McKie and Munshi (2007), Holtzhausen (2012), Ganesh and Zoller (2012), Holladay and Coombs (2013) all demonstrate the value of synergising a civic orientation with progressive visions of the roles of public relations practitioners within organisations. A strengthened societal orientation will also hold great utility for scholars who specialise in corporate public affairs because as Windsor (2005) has argued corporate legitimacy should be anchored in what are perceived to genuine contributions to the wider public interest.

This paper has focused on how public affairs and lobbying has been theorised and researched within public relations scholarship, but as Toth (1986) was observing over three decades ago there are particular difficulties in conceptualising public affairs for research purposes as the subject crosses so many different academic boundaries. There will be a clear utility in integrating public relations theory and empirical research with related disciplines, not least the scholarship in the field of interest groups. Largely located within political science, reviews of interest group research have revealed a common interest in campaigning tactics, relationships with stakeholders and the ability 
to mobilise and engage the grassroots as well as ongoing debates on measures for evaluating the efficacy of interest group activity (Hojnacki at al., 2012). Rather than accepting the assumptions of pure pluralism or political economy interest group research has frequently drawn upon neopluralism and assumes that while competition between groups exists this does not automatically equate to equal levels of influence or that policy outcomes will be fair (Godwin at al., 2012), but conversely that there is currently no conclusive proof that groups with more resources will predictably triumph in policy battles (Baumgartner et al., 2009). Indeed Ihlen has already encouraged recognition that in public affairs rhetorical resources exert varying levels of influence in different levels of society for different organisations (2002). The body of knowledge within interest group research based upon exchange models (Godwin et al., 2012) and the conceptualisation of lobbying as legislative information subsidy (Hall and Deardorff, 2006) are clearly also concepts that could usefully inform research designs within public affairs scholarship. But, there are also emerging themes and frameworks within public relations scholarship that hold great potential for developing a stronger theoretical underpinning on research that explores public affairs as a specialism. Habermas' conceptualisation of the public sphere and theories of communicative action are one obvious example, and there is great potential for applying discourse ethics (Meisenbach, 2006, Burkart, 2009) to lobbying in order to evaluate its impact on the quality of public discussions on important issues of public policy. In regards to applying social capital frameworks, Sommerfeldt (2013) has usefully argued the value of exploring the contributions made when practitioners build coalitions and collaborations between groups of citizens outside of their potentially rather homogenous everyday social networks. Alliances and coalitions are a core strategy for many public affairs campaigns, including those organised by activist groups who wish to challenge corporate influence, and stronger empirical data on how this impacts on indicators of social capital would assist in testing theory in this area.

Although public affairs research within public relations scholarship is dominated by functionalist and organisation-centric approaches, this study did not find any theoretical approach which could be said to constitute a dominant paradigm. Excellence theory was a discernible presence, but was not even the most frequently adopted approach, let alone the dominant one. Stakeholder theory was prominent as 
were theories that would sit broadly within the rhetorical paradigm (Heath et al., 2009) for studying public relations. There is an arguable value for a re-affirmation of the contribution that discursive paradigms will make to advancing future public affairs research agendas. Public affairs is communicative action (McGrath, 2007) and lobbying groups are rhetorical communities (Koeppl, 2001) that develop discursive strategies to pursue organisational objectives (Motion and Leitch, 1996), so much so that public affairs can be described as a "playground" for social reality construction (de Lange and Linders, 2006) and its practitioners as "discourse technologists" (Leitch and Motion, 2010). As such there would be utility in integrating the rhetorical paradigm into academic definitions of public affairs, for instance, Harris and Moss' (2001) definition could be adapted to state that public affairs is centred on managing relationships and the building of discursive communities across a broad range of stakeholder networks in order to create, re-create or replace shared interpretations of reality on any issue that may have policy implications.

This study found that almost all (97\%) scholarship on public affairs within public relations journals came from authors with institutional affiliations in Europe, the USA and Oceania. This finding leads to similar concerns as those expressed by Jelen (2008) that public relations is dominated by North American and western scholarship with the danger of academic ignorance of bodies of knowledge outside the English speaking world and McGrath et al's. (2010) argument that the public affairs literature is significantly weakened by its lack of a comprehensive global perspective, or Windsor's (2005) view that scholarship must become less ethnocentric. This is a problem that continues in extremis and threatens the validity of the field. This paper would argue that scholars in leadership positions within the field need to pro-actively seeks ways to rebalance the commissioning and publication of research in a manner which addresses the invisibility of the Global South.

The content analysis of journal content is intended as a starting point in exploring the theorising of public affairs within public relations scholarship, but possesses inevitable limitations. In considering and developing the validity of the content analysis, the literature review of previous papers that had conducted studies of journal content in public relations scholarship, and the rationale of their research designs were 
incorporated into the design of this study, such as the coding scheme, constructs, development of categories and approach to analysis. The intention being that this study not only reviews the state of the field in regard to public affairs, but also contributes to the longer stream of studies analysing PR journal content. The research design at all stages strove to defend the reliability of the study by reducing or removing any ambiguity in the construction of categories, but also by seeking to not impose concepts or interpretations, this was achieved through accepting the definition of theoretical approach or issue focus articulated by the author/s in each of the papers that were sampled. This process was certainly made more difficult by the lack of a strong consensus within the field of how to define or operationalise public affairs as well as by the interchangeable use within texts of the terms public relations, public affairs and lobbying. To protect the validity of the project articles were only sampled from journals that are recognised as core publishers of public relations scholarship. Articles that did not use the terms public affairs or lobbying were not included for analysis even when their subject matter might have been considered potentially relevant. These strict rules for including an article in the analysis resulted in a smaller sample, but also a more dependable one as it helped to ensure the analysis was not skewed by articles that were only tangentially concerned with public affairs and lobbying. There is certainly scope in future studies to widen out the criteria for inclusion in order to assess scholarship on public affairs that originate from fields such as political science or policy studies in order to explore the nature and quality of the empirical data that has been generated, as well as assessing the transferability of this data for use in public relations scholarship.

\section{Conclusion}

This study has demonstrated that the volume of scholarship exploring public affairs and lobbying within the public relations field is clearly insufficient to envisage the establishment of a mature body of theory and knowledge for quite some time yet. This is despite the widespread concerns of civic stakeholders over the ethics and impacts of this field of public relations practice, or the claims that this is an area of public relations practice with whose success or failure is more critical to the future of organisations than other specializations (Zetter, 2008: p. xiii). As such this paper would endorse Tusinski Berg's (2009) call for public relations scholars to claim lobbying as its own and develop 
research to address the ethical and communicative implications of lobbying activity.

This needs to be done in a manner that more equitably balances organisational and societal concerns.

\section{References}

An, S., \& Cheng, I. (2010). Crisis Communication Research in Public Relations Journals: Tracking. Chapter three In Coombs \& Holladay (eds) The handbook of crisis communication. Wiley-Blackwell.

Baumgartner, F. R., Berry, M., Hojnacki, M., Leech, B., \& Kimball, D. (2009). Lobbying and policy change: Who wins, who loses, and why. University of Chicago Press.

Baumgartner, F.\& Leech, B. (1998). Basic Interests: The Importance of Groups in Politics and in Political Science. Princeton, NJ.: Princeton University Press.

Beder, S. (2002). Global Spin: The Corporate Assault on Environmentalism (2nd ed.). Devon: Green Books.

Beurer-Zuellig, B., Fieseler, C. \& Meckel, M. (2009). A descriptive inquiry into the corporate communication profession in Europe. Public Relations Review, 35(3), pp. 270-279

Burkart, R. (2009).“On Habermas: Understanding and public relations. In: Ihlen, Ø. van Ruler, B \& Fredriksson, M. (eds.) Public relations and social theory: Key figures and concepts. New York, NY: Routledge, 141-165.

Boddewyn, J. (2012). Beyond 'The evolving discipline of public affairs. Journal of Public Affairs. 12(1): 98-104

Cheney, G., \& Christensen, L.T. (2001). Public Relations as Contested Terrain: A Critical Response, In Heath, R (Ed.),Handbook of Public Relations (pp. 167-182). Thousand Oaks, CA: Sage

Coombs, T., \& Holladay, S. (2012). Privileging an activist vs. a corporate view of public relations history in the US. Public Relations Review, 38(3), 347-353.

Cutler, A. (2004). Methodical failure: The use of case study method by public relations researchers. Public Relations Review, 30(3): 365-375.

de Bakker, F,. Groenewegen, P,. \& Den Hond, F. (2005). A bibliometric analysis of 30 years of research and theory on corporate social responsibility and corporate social performance. Business \& Society, 44(3), 283-317

de Lange, R., \& Linders, P. (2006). Public affairs as reality construction: an established paradigm with new implications. Journal of Public Affairs, 6(2), 131-146.

Demetrious, K. (2013) Public relations, activism, and social change - speaking up. Routledge, New York, N. Y

Dinan, W., \& Miller, D. (2007). Thinker, faker, spinner, spy: Corporate PR and the assault on democracy. Pluto Press.

Dutta, M. (2011). Communicating social change: Structure, culture, agency. New York: Routledge.

Edwards, L. (2006). Rethinking power in public relations. Public Relations Review, 32(3), 229-231.

Edwards, L. (2012). Defining the 'object’ of public relations research: A new starting point. Public Relations Inquiry, 1(1), 7-30.

Ferguson, M. (1984). Building theory in public relations: Interorganizational relationships as public relations paradigm. Paper presented to the annual conference of the Association for Education in Journalism and Mass Communication. August 1984. Gainesville, FL 
Finlayson, J. (2005). Habermas: A very short introduction. Oxford University Press.

Fleisher, C,. \& Blair, N. (1999) "Tracing the parallel evolution of public affairs and public relations: An examination of practice, scholarship and teaching", Journal of Communication Management, Vol. 3 Iss: 3 , pp. $276-292$

Fleisher, C. (2012). Anniversary retrospective, perspective and prospective of corporate public affairs: moving from the 2000+ PA Model toward Public Affairs 2.0. Journal of Public Affairs, 12(1), 4-11.

Ganesh, S,. \& Zoller, H. (2012). Dialogue, activism, and democratic social change. Communication Theory, 22(1), 66-91.

Getz, K. (2001). Public affairs and political strategy: Theoretical foundations. Journal of Public Affairs, 1/2(4/1): 305-329.

Godwin, R. K., Ainsworth, S., \& Godwin, E. K. (2012). Lobbying and Policymaking. CQ Press.

Grunig, J. E., \& Jaatinen, M. (1999). Strategic , Symmetrical Public Relations in Government: From Pluralism to Societal Corporatism, Journal of Communication Management, 3(3), 218 - 234

Grunig, J. E., Grunig, L,. \& Dozier, D. (2002) Excellent Public Relations and Effective Organizations: A Study of Communication Management in Three Countries, Lawrence Erlbaum, Mahwah, NJ.

Habermas J. (1989) The Structural Transformation of the Public Sphere: An Inquiry into a Category of Bourgeois Society. Cambridge, MA: MIT Press.

Habermas, J. (1996). Between facts and norms: Contributions to a discourse theory of law and democracy. Cambridge, MA: Polity Press.

Habermas, J. (2006). Political communication in media society: Does democracy still enjoy an epistemic dimension? The impact of normative theory on empirical research. Communication Theory, 16(4), 411-426.

Hall, R,. \& Deardorff, A (2006). Lobbying as legislative subsidy. American Political Science Review, 100(1), 69-84.

Harris, P., \& Fleisher, C. S. (Eds.). (2005). Handbook of Public Affairs. Sage.

Harris, P., \& Moss, D. (2001). In search of public affairs: A function in search of an identity. Journal of Public Affairs, 1(2), 102-110.

Hauser, G. (1998). Civil society and the public sphere. Philosophy and Rhetoric, 31, 19-40

Heath, R. (Ed.). (2010). The SAGE handbook of public relations. Sage.

Heath R,. Toth E,. \& Waymer D (eds) (2009). Rhetorical and Critical Approaches to Public Relations II. New York: Routledge

Heath, R,. Waymer,D,. \& Palenchar, M. (2013). Is the universe of democracy, rhetoric, and public relations whole cloth or three separate galaxies?, Public Relations Review, Volume 39, Issue 4, November 2013, Pages 271-279

Hillman, A. (2002). Public affairs, issue management and political strategy: Methodological issues that count a different view. Journal of Public Affairs, 1/2(4/1): 356-361.

Hojnacki, M,. Kimball, D,. Baumgartner, F,. Berry, J,. \& Leech, B. (2012). Studying Organizational Advocacy and Influence: Reexamining Interest Group Research. Annual Review of Political Science, 15, 379-399.

Holladay, S,. \& Coombs, T. (2013). Public relations literacy: Developing critical consumers of public relations. Public Relations Inquiry, 2(2), 125-146. 
Holmström, S. (1997). The inter-subjective and the social systemic public relations paradigms. Journal of Communication Management, 2(1), 24-39.

Holtzhausen, D. R. (2002). Towards a postmodern research agenda for public relations. Public Relations Review, 28(3), 251-264.

Holtzhausen, D.R. (2012). Public Relations as Activism. A Postmodern Approach to Public Relations Theory and Practice. New York: Taylor \& Francis/Routledge.

Ihlen, Ø. (2002). Rhetoric and resources: Notes for a new approach to public relations and issues management. Journal of Public Affairs, 2(4), 259-269

Ihlen, Ø. (2007). Building on Bourdieu: A sociological grasp of public relations. Public Relations Review, 33(3), 269-274.

Ihlen, Ø., \& Verhoeven, P. (2012). A public relations identity for the 2010s. Public Relations Inquiry, 1(2), 159176.

Jelen A (2008). The nature of scholarly endeavours in public relations. In: Van Ruler B, Verčič , A \& Verčič, D (eds) Public Relations Metrics: Research and Evaluation. New York and London: Routledge, pp.36-59.

Johnson, M.A. (2005). Five decades of Mexican public relations in the United Sates: From propaganda to strategic counsel. Public Relations Review, 31. 11-20.

Kamhawi, R., \& Weaver, D. (2003). Mass communication research trends from 1980 to 1999. Journalism \& Mass Communication Quarterly, 80(1), 7-27.

Koeppl, P. (2001). The Acceptance, Relevance and Dominance of Lobbying the EU Commission - A First-Time Survey of the EU Commission's Civil Servants. Journal of Public Affairs, 1: 69-80

Leitch, S,. \& Motion, J. (2010). Publics and public relations: Effecting change. In Heath, R (Ed.) The Sage Handbook of Public Relations (pp. 99-110). Thousand Oaks, CA: Sage.

L’Etang, J. (2008). Public relations concepts, practice and critique. London: Sage.

Macnamara, J. (2012). The global shadow of functionalism and Excellence Theory: An analysis of Australasian PR. Public Relations Inquiry 2012 1:367

McGrath, C. (2007). Framing lobbying messages: defining and communicating political issues persuasively. Journal of Public Affairs, 7(3), 269-280.

McGrath C,. Moss D,. \& Harris P. (2010). The evolving discipline of public affairs. Journal of Public Affairs 10(4): 335-352.

McKie, D. (2001). Updating public relations: “New science," research paradigms and uneven developments. In Heath, R (Ed.), Handbook of Public Relations (pp. 75-91). Thousand Oaks: Sage Publications.

McKie, D,. \& Munshi, D. (2007). Reconfiguring public relations: Ecology, equity, and enterprise. London: Routledge

Meisenbach, R. (2006). Habermas’s discourse ethics and principle of universalization as a moral framework for organizational communication. Management Communication Quarterly. 20 (1), 39-62

Meisenbach, R \& Feldner, S. (2007). “SaveDisney.com and activists challenges: A Habermasian perspective on corporate legitimacy”. International Journal of Strategic Communication. 1 (4), 207-226

Meznar, M. (2001). The theoretical foundations of public affairs and political strategy: Where do we go from here?. Journal of Public Affairs, 1(4), 330-335

Milbrath, L. (1963). The Washington Lobbyists. Chicago: Rand McNally. 
Miller, D., \& Harkins, C. (2010). Corporate strategy, corporate capture: food and alcohol industry lobbying and public health. Critical Social Policy, 30(4), 564-589.

Moloney, K. (2006). Rethinking public relations: PR propaganda and democracy. Routledge.

Motion, J., \& Leitch, S. (1996). A discursive perspective from New Zealand: Another world view. Public Relations Review, 22,297-309

Motion, J., \& Weaver, C. K. (2005). A discourse perspective for critical public relations research: life sciences network and the battle for truth. Journal of Public Relations Research, 17(1), 49-67.

Morton, L. \& Lin, L. (1995). Content and citation analyses of Public Relations Review. Public Relations Review, 21, 337-349.

OECD. (2009). Lobbyists, Government and Public Trust: Promoting Integrity by Self-Regulation. Paris: OECD, October, GOV/PGC(2009)9

Pasadeos,. Y \& Renfro, B. (1992). A bibliometric analysis of public relations research. Journal of Public Relations Research 4(3), 167-187.

Pasadeos,. Y. Renfro, B \& Hanily, M (1999). Influential authors and works of public relations scholarly literature: A network of recent research, Journal of Public Relations Research 11(1), 29-52

Pasadeos,. Y. Berger, .B, \& Renfro, R. (2010). Public relations as a maturing discipline: An update on research networks. Journal of Public Relations Research, 22(2), 136-158.

Pavlik, J. (1987). Public relations: What research tells us (Vol. 16, Sage CommText Series). Newbury Park, CA: Sage.

Political and Constitutional Reform Committee (2012). Introducing a statutory register of lobbyists. House of Commons Political and Constitutional Reform Committee. Second Report of Session 2012-13. Volume II Additional Written Evidence. Published on 13 July 2012. London: The Stationary Office Limited.

Potter, W,. \& Riddle, K. (2007). A content analysis of the media effects literature. Journalism \& Mass Communication Quarterly, 84(1), 90-104.

Putnam, R. D. (1995). Bowling alone: America’s declining social capital. Journal of Democracy, 6, 65-78.

Rice, C,. \& Somerville, I. (2013). Power-sharing and political public relations: Government-press relationships in Northern Ireland's developing democratic institutions. Public Relations Review, 39(4), 293-302.

Saloojee, Y., \& Dagli, E. (2000). Tobacco industry tactics for resisting public policy on health. Bulletin of the World Health Organization, 78(7), 902-910.

Sallot, L,. Lyon, L,. Acosta-Alzuru, C,. \& Jones, K. (2003). From aardvark to zebra: A new millennium analysis of theory development in public relations academic journals. Journal of Public Relations Research, 15, 27-90.

Sisco, H,. Collins, E,. \& Zoch, L. (2011). Breadth or depth? A content analysis of the use of public relations theory. Public Relations Review. Volume 37, Issue 2, June 2011, Pages 145-150

Smudde, P,. \& Courtright, J. (2010) Public relations and power. In: Heath RL (ed.) The SAGE Handbook of Public Relations. Thousands Oaks, CA: Sage, pp.177-90.

Somerville, I. (2011). Managing public affairs and lobbying: persuasive communication in the policy sphere. Chapter Seven in Moss, D \& DeSanto, B (eds) : Public Relations: A Managerial Perspective. Sage, pp. 167-193

Somerville, I \& Ramsey, P. (2012) Public Relations and Politics. In the Public Relations Handbook. Eds: Theaker, A, Routledge, pp. 38-59. 
Sommerfeldt, E.(2013). The civility of social capital: Public relations in the public sphere, civil society, and democracy, Public Relations Review, Volume 39, Issue 4, November 2013, Pages 280-289

Stauber, J,. \& Rampton, S. (1995). Toxic Sludge is Good for You!: Lies, Damn Lies and the Public Relations Industry. Boston: Common Courage Press.

Stone, P. H. (2006). Heist: Superlobbyist Jack Abramoff, his Republican allies, and the buying of Washington. Macmillan.

Stromback, J., \& Kiousis, S. (2011). Political Public Relations: Principles and Application. Routledge

Taylor, M. (2009). Civil society as a rhetorical public relations process. In Heath, R \& Waymer, D. (Eds), Rhetorical and critical approaches to public relations II, Lawrence Erlbaum Associates, Hillsdale, NJ, pp. 7691)

Terry, V. (2001). Lobbyists and their stories: Classic PR practitioner role models as functions of Burkean human motivations. Journal of Public Relations Research, 13, 235- 263.

Toth, E. L. (1986). Broadening research in public affairs. Public Relations Review, 12(2), 27-36.

Toth, E. L. (2006). Building public affairs theory. In V. Hazelton \& C. Botan (Eds.),Public relations theory II (pp. 499-522). Mahwah, NJ: Lawrence Erlbaum Publishers, Inc.

Tusinski Berg, K. (2009). Finding connections between lobbying, public relations and advocacy. Public Relations Journal, 3(3), 1-19.

Valentini, C. (2009). Italian public relations in a changing world: Historical overview, current questions and future challenges. PRism 6(2): http://www.prismjournal.org/fileadmin/Praxis/Files/globalPR/VALENTINI.pdf

Valentini, C,. Kruckeberg, D,. \& Starck, K. (2012). Public relations and community: A persistent covenant. Public Relations Review. Volume 38, Issue 5, Pages 873-879

Verčič, D., \& Tkalac Verčič, A. (2012). Public relations and lobbying: New legislation in Slovenia. Public Relations Review, 38(1), 14-21.

Ward, I. M. (2009). Lobbying as a public affair. PR and politics in Australia. In: Flew, Terry, Communication, Creativity and Global Citizenship. Communication, Creativity and Global Citizenship: Refereed Proceedings of the Australian and New Zealand Communication Association Conference 2009, Brisbane, Australia, (10391056). July 8-10.

Windsor D (2005). Theories and Theoretical Roots of Public Affairs. In the Handbook of Public Affairs, Harris P, Fleisher CS (eds). Sage: Thousand Oaks, CA; 401-417

Wise, K. (2007). Lobbying and relationship management: The K Street connection. Journal of Public Relations Research, 19(4), 357-376.

Yang, A,. \& Taylor, M (2013). The relationship between the professionalization of public relations, societal social capital and democracy: Evidence from a cross-national study. Public Relations Review, Volume 39, Issue 4, November 2013, Pages 257-270

Ye, L., \& Ki, E. (2012). The Status of Online Public Relations Research: An Analysis of Published Articles in 1992-2009. Journal of Public Relations Research, 24(5), 409-434.

Zetter, L. (2008). Lobbying: the art of political persuasion. Harriman House Limited.

Zoch, L., Collins, E., \& Fussell Sisco, H. (2007). Maintaining momentum in the new millennium?: a descriptive analysis of scholarly public relations articles in selected communication journals 2001-2005. Paper presented at the 57th Annual Meeting of the International Communication Association, San Francisco, CA, USA, 24-28 May 2007 